\title{
Electron-microscopic study of developmental stages of Goussia balatonica and G. pannonica (Apicomplexa: Eimeriorina), parasites of white bream Blicca bjoerkna
}

\author{
Kálmán Molnár, Ferenc Baska \\ Veterinary Medical Research Institute, Hungarian Academy of Sciences, PO Box 18, H-1581 Budapest, Hungary
}

\begin{abstract}
Merogonic and gamogonic stages of Goussia balatonica and G. pannonica, 2 intestinal parasites of white bream Blicca bjoerkna L., were studied by electron microscopy. G. balatonica Molnár, 1989 develops in the gut epithelium in nodules visible with the unaided eye. All developmental stages are located in the cytoplasm, in supranuclear position, in a parasitophorous vacuole. G. pannonica Molnár, 1989 is a typical epicellularly developing parasite. All of its developmental stages are situated in an extracytoplasmatically located parasitophorous vacuole within the epithelial cells. Towards the gut lumen the membrane of the parasitophorous vacuole is covered by a single unit membrane which is a continuation of the unit membrane of intestinal epithelial cell microvilli. Persistence of the conoid was a common finding for gamogonic stages of both parasites.
\end{abstract}

\section{INTRODUCTION}

In an earlier paper, Molnár (1989) reported that 2 distinct coccidium species occur regularly in the gut of cyprinid white bream Blicca bjoerkna L. in early spring. The 2 species differ in size and location within the host. While Goussia balatonica Molnár, 1989 forms nodules (aggregations of merogonic and gamogonic stages in the intestinal epithelium), G. pannonica Molnár, 1989 occurs epicellularly in the apical region of intestinal epithelial cells, showing uniform distribution over larger areas.

Electron-microscopic study of fish-parasitic coccidia developing in nodules is linked with the name of Lom (1971), who studied the oocysts of Eimeria subepithelialis and E. spleni. Of the early stages of noduleforming fish coccidia, only the gamogonic stages of Goussia subepithelialis have been studied (Steinhagen et al. 1990), though recently such coccidia have been found to occur in the gut of several cyprinids other than the common carp (Molnár 1982, 1989, Jastrzebski 1984).

Of epicellularly developing coccidia, Eimeria(Epieimeria-) type species are better documented in the specialized literature. Molnár \& Baska (1986) studied the intracellular location of different developmental stages of Epieimeria anguillae parasitic in eel intestine. In her monograph on the coccidia of marine fishes, Daoudi (1987) described the ultrastructural features of merogonic and gamogonic stages of a further 2 species, Epieimeria isabellae and E. puytoraci. Epicellularly developing coccidia belonging to the Goussia group have been reported on by Molnár $(1986,1989)$, Landsberg \& Paperna (1987), Kent et al. (1988), Jastrzebski \& Komorowski (1990), and Lukes \& Dykova (1990).

This report describes the ultrastructural features of merogonic and gamogonic stages of Goussia balatonica and $G$. pannonica, developing in nodules and epicellularly, respectively, in intestine of white bream.

\section{MATERIALS AND METHODS}

Test material was obtained by dissecting naturally infected, 2- to 3-summer white bream caught from lake Balaton, Hungary, and examined between 1987 and 1989. This material was the same as that examined by Molnár (1989) by light microscopy. In March and April, the time when coccidiosis was expected to occur, initial mucus and epithelial scrapings were taken from the gut. Subsequently, for electron microscopy, pieces several $\mathrm{mm}^{3}$ in volume were excised from the intestinal 
epithelium in areas infected by developmental stages of coccidia. The tissue pieces were fixed in $5 \%$ glutaraldehyde dissolved in $0.13 \mathrm{M}$ sodium cacodylate buffer ( $\mathrm{pH} \mathrm{7.4)}$ for $2 \mathrm{~h}$, washed with $0.13 \mathrm{M}$ sodium cacodylate, postfixed in $1 \% \mathrm{OsO}_{4}$, and embedded in synthetic resin (Durcupar). Sections cut with a Reichert OM-U2 ultramicrotome were examined in JEOL 100-S and Philips 201 CS electron microscopes.

\section{RESULTS}

\section{Goussia balatonica}

Macrogamonts and microgamonts of Goussia balatonica were easily observable by electron microscopy in almost all epithelial cells in samples taken from nodules visible with the unaided eye (Fig. 1). Merogonic stages (Fig. 2) were detectable only in preparations fixed in March, from sites at which massive infection had been indicated by the presence of large masses of freely moving merozoites in fresh preparations of mucus. Both the merogonic and the gamogonic stages were located in the cylindrical intestinal epithelial cells, apical to the nucleus, within a parasitophorous vacuole.

Meronts containing at least 8 but at most 16 merozoites proved to be the youngest stages seen by us (Fig. 2). Their exact number could not be determined. Parasitophorous vacuoles containing banana-shaped merozoites were surrounded by a narrow cytoplasmic band of the host cell. In the parasitophorous vacuole, among the merozoites, large numbers of membranebound spherical bodies 40 to $260 \mathrm{~nm}$ in size occurred. The merozoites were bordered by a 30 to $45 \mathrm{~nm}$ thick pellicle. Their cytoplasm was densely filled with free ribosomes, granular endoplasmic reticula and, probably due to a fixing error, large (410 to $830 \mathrm{~nm}$ ) vacuole-like mitochondria (Fig. 2). The heterochromatic nucleus of the merozoite was located centrally in the body, with a distinct central nucleolus and electrondense chromatin aggregations on the cell membrane. At the anterior end of the merozoites large numbers of micronemes could be found; in certain specimens (Fig. 2) the conoid was also distinct. From the nucleus towards the conoid 4 to 6 highly electron-dense rhoptries were seen.

It was not possible to study young microgamonts containing only a few nuclei. In more mature microgamonts $14-18 \times 10-14 \mu \mathrm{m}$ in size, 8 to 30 nuclei were seen in the plane of sectioning in the marginal part of the cytoplasm (Fig. 3). The microgamont was surrounded by a unit membrane and separated from the host cell by a parasitophorous vacuole. Certain microgamonts contained remnants of the conoid, situated close to the membrane, even at this late stage (Fig. 4). The nucleoplasm of nuclei drawn towards the periphery was divided into an electron-dense external and a less electron-dense internal part (Fig. 5). The former constituted the head part of the forming microgametes, while the latter was retained in the residual part of the microgamont. Above nuclei that had drawn towards the surface, electron-dense material appeared on the cell membrane of the gamont, at the location of the future perforatorium (Fig. 5). Carrying the nuclear substance of the gametes with it, this material rose above the surface (Fig. 6). In the mature microgamonts, the transected heads of the microgametes and flagella that had formed were seen surrounding the residual material (Fig. 7).

Macrogamonts $14-17 \times 12-16 \mu \mathrm{m}$ in size (Fig. 8) were situated within the parasitophorous vacuole. They contained a central electron-opaque nucleus which enclosed a round electron-dense nucleolus. In the cytoplasm of the macrogamont, large electrondense formations, amylopectin and lipid inclusion bodies occurred together with innumerable free ribosomes (Fig. 8). The membrane of the gamont could not be studied in more detail under the magnification applied.

\section{Goussia pannonica}

All developmental stages of Goussia pannonica observed by us were located in the epiplasm of epithelial cells (Fig. 9). The parasites protruded from the epithelial surface and microvilli into the gut lumen. The parasitophorous vacuole surrounding them was composed of a unit membrane organized from host-cell plasma membranes. Towards the gut lumen this unit membrane was closely associated with the membrane of microvilli, as similarly described by Molnár \& Baska (1986), Daoudi (1987), and Paperna \& Landsberg (1987) (Figs. 9 to 13). Basally the membrane of the parasitophorous vacuole joined the hast-cell cytoplasm at a single smooth surface; however, in the marginal parts and towards the microvilli the vacuole showed numerous protrusions (Figs. $10 \& 11$ ).

The youngest stages found were meronts containing 4 to 8 merozoites (Fig. 11) around which the parasitophorous vacuole sent out numerous protrusions among the microvilli. The banana-shaped merozoites occurred freely in the parasitophorous vacuole; among them, membrane-bound corpuscles were located freely

Young trophozoites, probably macrogamonts (Figs. 9 \& 10), had a large nucleus and micronemes located peripherally in the plasm. Young multinucleated microgamonts contained 5 to 16 nuclei (Fig. 12). The nuclei 


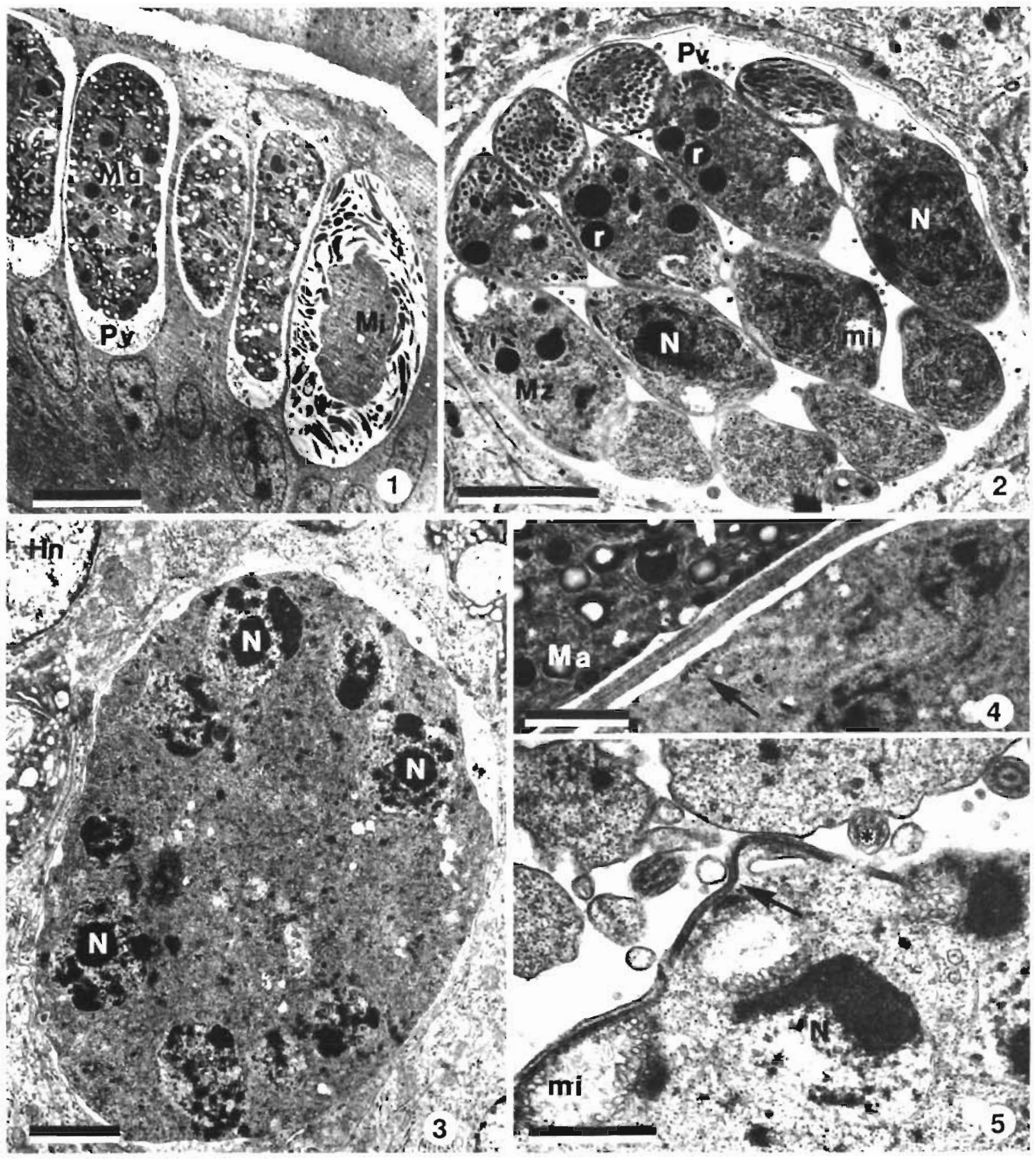

Figs. 1 to 5. Goussia balatonica. Fig. 1. Macrogamonts (Ma) and microgamonts ( $\mathrm{M}_{1}$ ) located supranuclearly, in the parasitophorous vacuole (Pv). Scale bar $=10 \mu \mathrm{m}$ Fig 2 Cross-section of merozoltes $(\mathrm{Mz})$ The merozoltes are located freely in the parasitophorous vacuole (Pv). N: Nucleus of the merozolte, r rhoptnes; mi. mitochondrium Scale bar $=2$ um. Fig 3 Young microgamont tightly filling the parasitophorous vacuole Note heterochromatic nuclel $(\mathrm{N})$ in the periphery of its cytoplasm Hn Host cell nucleus. Scale bar $=2 \mu \mathrm{m}$ Fig. 4. Remnants of the conold (arrow) in the cytoplasm of a microgamont Ma Macrogamont. Scale bar $=2 \mu \mathrm{m}$. Fig. 5 Formation of microgametes Below the cell membrane of the microgamont note the cross-section of electron-dense lamellae (arrow) of the perforatorium Under the latter, tubular mitochondria (mi) of a hetrochromatic nucleus $(N)$ can be observed. Note the cioss-sections of flagella ( $)$ in the lumen of the parasitophorous vacuole 

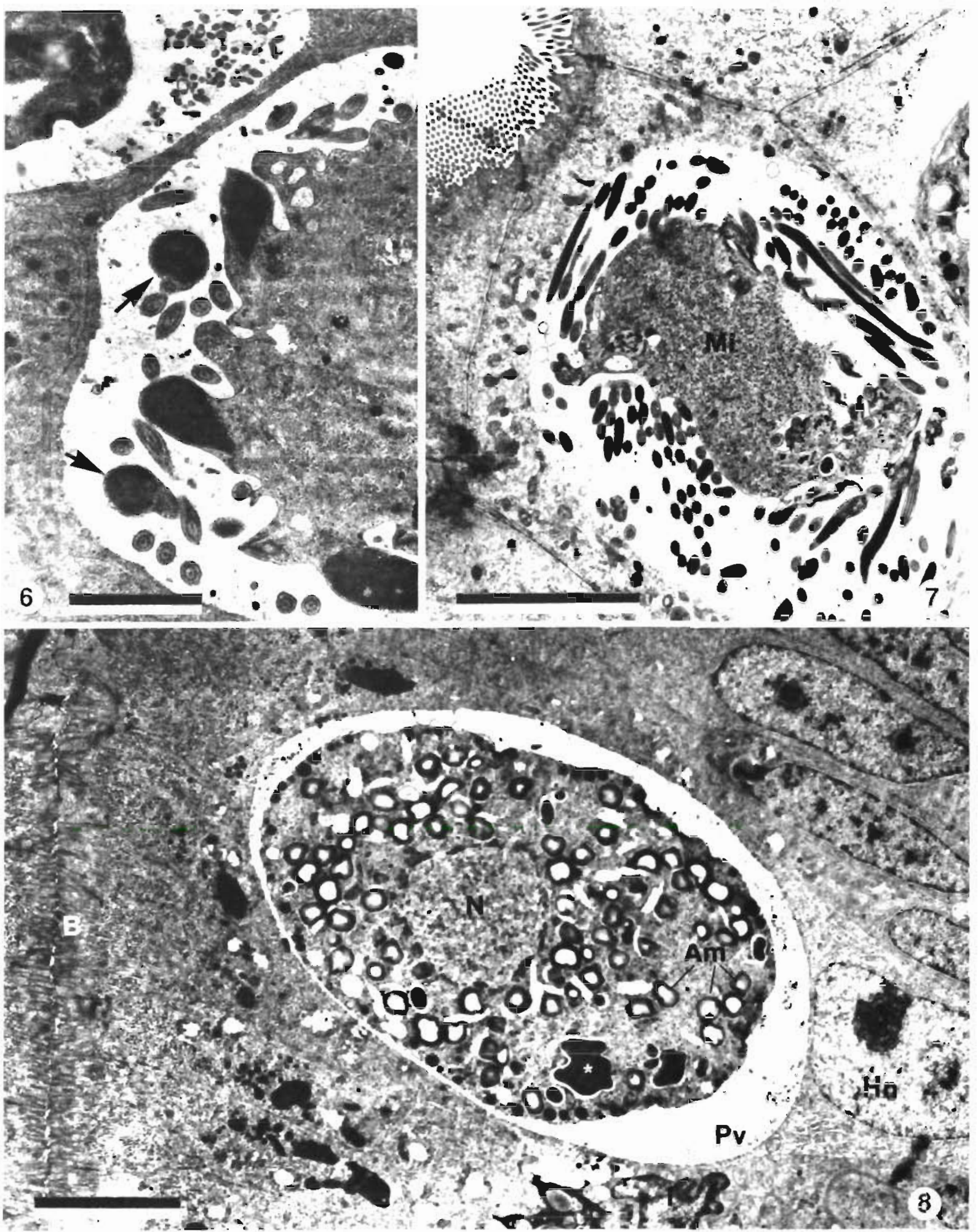

Figs 6 to 8. Goussia balatonica. Fig. 6. Formation of microcametes Cross-sections of free microgametes (arrows) and electrondense head parts separating from the microgamont cytoplasm are seen in the parasitophorous vacuole. Scale bar $=2 \mu \mathrm{m}$. Fig. 7 . Mature microgamont (Mi). Cross-sections of numerous mature microgametes are seen in the parasitophorous vacuole. Scale bar $=5 \mathrm{um}$. Fig. 8. Mature macrogamont in the parasitophorous vacuole (Pv). Note the centrally located euchromatic nucleus ( $N$ ). The cytoplasm is filled by amylopectin and large electron-dense inclusions ( Ho Host cell nucleus; B: brush border Scale bar 

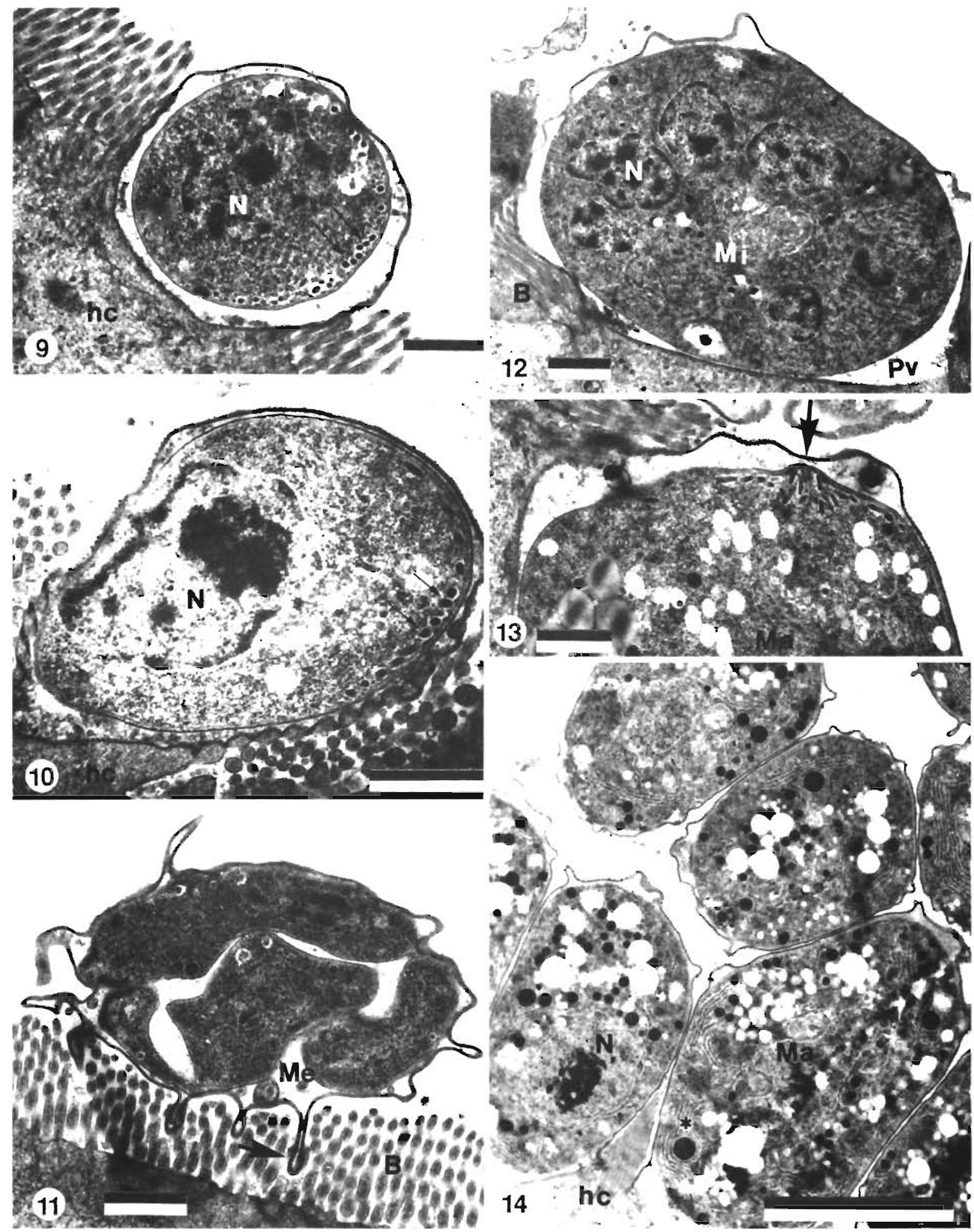

Figs. 9 to 14. Goussia pannonica. Figs. 9 \& 10. Young trophozoites in epicellular position. N: Nucleus of the trophozoite; hc: hostcell cytoplasm; arrows indicate micronemes. Scale bar $=1 \mu \mathrm{m}$. Fig. 11. Meront (Me) containing cross-sections of 4 merozoites and sending out projections (arrow) into the brush border (B). Scale bar $=1 \mu \mathrm{m}$. Fig. 12. Young microgamont (Mi) in the cavity of the epicellularly formed parasitophorous vacuole (Pv). N: Nuclei of the microgamont; B: brush border Scale bar = 1 um. Fig. 13. Detail of a young macrogamont (Ma). The persistent conoid (arrow) is clearly observable. Scale bar $=1$ um. Fig. 14. Cross-sections of several macrogamonts (Ma) located epicellularly. hc: Host cell; N: nucleus of the macrogamont; endoplasmic reticulum. 
were gradually pushed towards the periphery during microgamont development and multiplied. Unfortunately, no mature microgamonts could be studied.

In infected areas, the majority of coccidia were constituted by developing macrogamonts (Figs. 13 \& 14) situated within a relatively narrow parasitophorous vacuole. Laterally the membrane of the vacuole formed characteristic protrusions while basally it displayed a uniform surface (Fig. 13).

Besides the centrally located nucleus, we observed amylopectin, lipid and electron-dense granules in the developing macrogamonts. The macrogamonts were rich in endoplasmic reticulum exhibiting a fingerprintlike arrangement, and in free ribosomes (Figs. $13 \& 14$ ). It was striking to note that the young macrogamonts contained remnants of the conoid and comma-shaped micronemes surrounding them (Fig. 13). In older macrogamonts the remnants of micronemes were situated in the ectoplasm, along the cell membrane.

\section{DISCUSSION}

As had already been indicated by the light microscopic studies (Molnár 1989), electron microscopy demonstrated that white bream Blicca bjoerkna have 2 similar coccidian species, well distinguishable by their location within the host.

In the case of Goussia balatonica, the development of nodules protruding from the surface of the gut epithelium, visible with the unaided eye, could be explained by the fact that during gamogony the developmental stages were restricted to a given segment of the gut epithelium where they infected almost all epithelial cells. The merogonic stages show practically the same structure as described by Paterson \& Desser (1981a) and Hawkins et al. (1984) for Eimeria iroquoina and Calyptospora funduli respectively. The corpuscles occurring freely in the parasitophorous vacuole among the merozoites probably correspond to residual bodies remaining from the meront. The macrogamonts were primarily characterized by the presence of large numbers of lipid and amylopectin granules; however, granules termed electron-dense inclusions, identified by some investigators (Hawkins et al. 1984, Morrison \& Hawkins 1984, Paperna 1990) with the wall-forming bodies of oocysts and sporocysts, were also demonstrated. In contrast, Paterson \& Desser (1981c), Desser \& Li (1984), and Morrison \& Poynton (1989) considered them identical with the refractile granule of the sporoblast and sporozoite. We hold the view that $G$. balatonica, which has extremely thin oocyst and sporocyst walls, does not need as much wall-forming material as is accumulated in these dense inclusions. Therefore, similarly to Jastrzebski \&
Komorowski (1990), we have our doubts about the wall-forming function. Besides the granules mentioned above, the presence of small electron-dense granules along the periphery is highly typical, primarily of young macrogamonts. In our opinion, these derive from the micronemes of merozoites and are not identical with the much larger, mostly centrally located dense forms. We risk the assumption that it is these latter granules which take part in the formation of the oocyst and sporocyst wall.

The course of microgamogony and the structure of microgametes in the 2 species studied essentially correspond to the description of Paterson \& Desser (1981b). It is surprising, however, that in some microgamonts the remnants of the conoid can be observed even at an advanced stage of gamogony. Persistence of the conoid in fish coccidia was reported by Jastrzebski \& Komorowski (1990). The almost identical size of microgamonts and macrogamonts is also striking, since in the case of the closely related Goussia subepithelialis Steinhagen et al. (1990) found the microgamonts much larger than the macrogamonts.

Goussia pannonica is a typical epicellular parasite. Previously, the only parasites known to develop epicellularly were Eimeria anguillae and E. pigra. Based upon its typical location, Dykova \& Lom (1981) created for $E$. anguillae a new genus, Epieimeria, to which they also assigned Epieimeria isabellae and E. puytoraci in addition to the above species. At the same time, Goussia (Eimeria) pigra and other, subsequently described goussias exhibiting similar epicellular location but having a typical Goussia structure (G. acipenseris, G. girellae, G. zarnowskii) remained in the genus Goussia. $G$. pannonica, which differs only slightly in location from E. anguillae (also studied by us; Molnár \& Baska 1986), also belongs to this latter group. Similarly to all Epieimeria and 'Epigoussia' species, G. pannonica is located in the host-cell ectoplasm, in a vacuole formed by the membrane of microvilli, which is only basally contiguous with the host-cell cytoplasm. In the case of known epicellular parasites, however, this contact varies among species. While in E. anguillae and E. isabellae close contact is maintained through protrusions of the parasitophorous vacuole into the host-cell cytoplasm (Molnár \& Baska 1986, Daoudi 1987), in Eimeria (Goussia) vanasi the relationship of the parasitophorous vacuole to the host cell is somewhat different. According to Paperna \& Landsberg (1987), in this species long, tubular formations extend from the parasitophorous vacuole into the host-cell cytoplasm. In Jastrzebski \& Komorowski's (1990) view, the protrusions of the parasitophorous vacuole of $G$. zarnowskii above all resemble those observed for $E$. anguillae; the latter, however, contain numerous electron-dense granules which, according to Jastrzebski \& Komo- 
rowski, may serve for excretion. In the case of $G$. pannonica, the connection between the parasitophorous vacuole and the epithelial cell cytoplasm is conspicuously smooth, free of protrusions. However, from some parts of the vacuole contiguous with the microvilli long projections extend towards the cytoplasm. Similar observations have been made by Daoudi (1987) for $E$. puytoraci.

The conoid and masses of micronemes persisting in the macrogamonts of Goussia pannonica are especially striking. These formations can be found even in gamonts at an advanced stage of maturation.

\section{LITERATURE CITED}

Daoudi, F. (1987). Coccidies et coccidioses de poissons mediterraneens: systématique, ultrastructure et biologie. Ph.D. thesis. Université des Sciences Techniques du Languedoc, Montpellier

Desser, S. S., Li, L. (1984). Ultrastructural observations on the sexual stages and oocyst formation in Eimeria laureleus (Protozoa, Coccidia) of perch, Perca flavescens, from Lake Sasajewun, Ontario. Z. Parasitkde 70: 153-164

Dykova, I., Lom, J. (1981). Fish coccidia: critical notes on life cycles, classification and pathogenicity. J. Fish Dis. 4: $487-505$

Hawkins, W. E., Fournie, J. W., Overstreet, R. M. (1984) Intrahepatic stages of Eimeria funduli (Protista: Apicomplexa) in the longnose killifish, Fundulus similis. Trans. Am. microsc. Soc. 103(2): 185-194

Jastrzebski, M. (1984). Cocciofauna of cultured and feral fishes in fish farms. Wiad. Parazytol. 30: 141-170

Jastrzebski, M., Komorowski, Z. (1990). Light and electron microscope studies on Goussia zarnowskii (Jastrzebski, 1982): an intestinal coccidium parasitizing the threespinned stickleback, Gasterosteus aculeatus L. J. Fish Dis. 13: $1-24$

Kent, M. L., Fournie, J. W., Snodgrass, R. E., Elston, R. A (1988). Goussia girellae n. sp. (Apicomplexa: Eimeriorina) in the opaleye, Girella nigricans. J. Protozool. 35: 287-290

Landsberg, J. H., Paperna, I. (1987). Intestinal infections by Eimeria (s. 1.) vanasi n. sp. (Eimeriidae: Apicomplexa, Protozoa) in cichlid fish. Annls Parasit. hum. comp. 62: 283-293

Responsible Subject Editor: W. Körting, Hannover, Germany
Lom, J. (1971). Remarks on the spore envelopes in fish coccidia. Folia Parasitol. Prague 18. 289-293

Lukes, J., Dykova, I. (1990). Goussia janae n. sp. (Apicomplexa, Eimeriorina) in dace Leuciscus leuciscus and chub L. cephalus. Dis. aquat. Org. 8: 85-90

Molnar, K. (1982). Nodular coccidiosis in the gut of the tench, Tinca tinca L. J. Fish Dis. 5: 461-470

Molnár, K. (1986). Occurrence of two new Goussia species in the intestine of the sterlet (Acipenser ruthenus). Acta Vet. Hung. 34: 169-174

Molnár, K. (1989). Nodular and epicellular coccidiosis in the intestine of cyprinid fishes. Dis. aquat. Org. 7: 1-12

Molnár, K., Baska, F. (1986). Light and electron microscopic studies on Epieimeria anguillae (Leger \& Hollande, 1922), a coccidium parasitizing the European eel. Anguilla anguilla L. J. Fish Dis. 9: 99-110

Morrison, C. M., Hawkins, W. E. (1984). Coccidians in the liver and testis of the herring Clupea harengus L. Can. J. Zool. 62: 480-493

Morrison, C. M., Poynton, S. L. (1989). A new species of Goussia (Apicomplexa, Coccidia) in the kidney tubules of the cod, Gadus morhua L. J. Fish Dis. 12: 533-560

Paperna, I. (1990). Fine structure of the gamonts of Eimeria (s. 1.) vanasi, a coccidium from the intestine of cichlid fishes. Dis. aquat. Org. 9: 163-170

Paperna, I., Landsberg, J. H. (1987). Tubular formations extending from parasitophorous vacuoles in gut epithelial cells of cichlid fish infested by Eimeria (s. 1.) vanasi. Dis. aquat. Org. 2: 239-242

Paterson, W. B., Desser, S. S. (1981a). An ultrastructural study of Eimeria iroquina Molnár \& Fernando, 1974 in experimentally infected fathead minnows (Pimephales promelas, Cyprinidae). 3. Merogony. J. Protozool. 28 : 302-308

Paterson, W. B., Desser, S. S. (1981b). An ultrastructural study of microgametogenesis and the microgamete in experimentally infected fathead minnows Pimephales promelas (Cyprinidae). J. Parasit. 67: 314-324

Paterson, W. B., Desser, S. S. (1981c). Ultrastructure of macrogametogenesis, macrogametes and young oocyst of Eimeria iroquina Molnár \& Fernando 1974 in experimentally infected fathead minnows (Pimephales promelas, Cyprinidae). J. Parasit. 67: 496-504

Steinhagen, D., Lukes, J., Körting, W (1990). Ultrastructural observations on gamogonic stages of Goussia subepithelialis (Apicomplexa, Coccidia) from common carp Caprinus carpio. Dis. aquat. Org. 9: 31-36

Manuscript first received: November 30, 1991

Revised version accepted: April 29, 1992 